\title{
СОВРЕМЕННОЕ СОСТОЯНИЕ И ТЕНДЕНЦИИ РАЗВИТИЯ АГРАРНОГО СЕКТОРА ЭКОНОМИКИ РЕСПУБЛИКИ БАШКОРТОСТАН
}

\section{(c) 2019 Садыкова Лилия Гайсаевна}

кандидат экономических наук, доцент кафедры экономики и управления

Стерлитамакский филиал Башкирского государственного университета, Россия, Стерлитамак

E-mail: lilsadyk@yandex.ru

Для развития и роста сельскохозяйственного производства в регионе необходимо изучение его потенциала для эффективного развития. В статье рассматриваются потенциал региона и приоритетные направления развития агропромышленного комплекса на примере Республики Башкортостан. Проведен анализ государственной поддержки аграрного сектора экономики. Выявлены проблемы и предложены пути повышения эффективности сельскохозяйственного производства в современных условиях.

Ключевые слова: сельское хозяйство, государственная поддержка, сельскохозяйственная продукция, доходогенерирующие проекты, сельскохозяйственные потребительские кооперативы, крестьянские (фермерские) хозяйства, личные подсобные хозяйства.

Благоприятные природно-климатические условия, плодородные земли, государственная поддержка и инвестиционные проекты - все это обуславливает развитие сельского хозяйства в регионе.

В 2018 году в республике собрано свыше 3,3 млн. т зерна, объем продукции аграрного сектора экономики достиг 120 млрд. руб. В аграрный комплекс вложено 5,8 млрд. руб. В республике увеличиваются объемы субсидий на покупку современной сельскохозяйственной техники. С начала 2018 года хозяйства приобрели 1400 единиц сельскохозяйственной техники, при этом, она производится в республике. Например, сборка тракторов «Беларус» осуществляется на предприятии «Башсельхозтехника».

Республика Башкортостан занимает первое место в России по производству говядины и второе место - по молоку.

По данным Министерства сельского хозяйства Республики Башкортостан, в 2017 году в республике произведено 1,7 млн. т молока. При этом надой увеличился на 3\%, достигнув рекордной для региона исторической цифры в пять тысяч килограммов на фуражную корову. Более шести тысяч килограммов молока от одной коровы получено в Учалинском, Чекмагушевском и Аургазинском районах.

Республика Башкортостан занимает десятое место в стране и второе в Приволжском федеральном округе по производству мяса скота и птицы. Регион сохраняет первое место в России по производству говядины - около 190 тысяч тонн.

Таблица 1. Динамика основных показателей агропромышленного комплекса Республики Башкортостан

\begin{tabular}{|c|c|c|c|c|c|}
\hline Показатель & 2005 & 2010 & 2017 & 2018 & $\begin{array}{c}2018 \text { к } 2017, \\
\text { в \% }\end{array}$ \\
\hline $\begin{array}{l}\text { Объем валовой продукции, } \\
\text { млрд. руб. }\end{array}$ & 60,4 & 88,6 & 171,8 & 154,5 & 89,9 \\
\hline $\begin{array}{l}\text { Индекс производства пищевых } \\
\text { продуктов, в\% }\end{array}$ & 106 & 96,3 & 105,0 & 100,5 & $-4,5$ \\
\hline \multicolumn{6}{|l|}{ Объем производства, тыс. т: } \\
\hline Молоко & 2083,4 & 2078,1 & 1718,4 & 1700,0 & 98,9 \\
\hline Мясо & 381,6 & 467,1 & 410,2 & 400,0 & 97,5 \\
\hline \multicolumn{6}{|l|}{ Валовый сбор, тыс. т } \\
\hline Зерно & 2884 & 781 & 3783 & 3359 & 88,8 \\
\hline Сахарная свекла & 1176 & 377 & 1594 & 1428 & 89,6 \\
\hline Подсолнечник & 126 & 51 & 274 & 319 & 116,4 \\
\hline Овощи и картофель & 1501 & 663 & 1346 & 1223 & 90,9 \\
\hline
\end{tabular}


В 2017 году был получен рекордный за последние пять лет урожай зерновых: выращено более 3,783 млн. т. В 2018 году намолочено 3,15 млн.т зерна. Увеличились площади высокомаржинальных культур (льна, рапса, горчицы) и производство овощей, в частности, сахарной свеклы, подсолнечника.

Приоритетные направления развития отраслей агропромышленного комплекса Республики Башкортостан до 2020 года представлены в таблице 2 .

В республике имеется значительный потенциал для дальнейшего роста. Необходимо делать ставку на высокомаржинальные культуры, активнее внедрять достижения агронауки, современные технологии, высокоточное земледелие, когда гектар правильно удобренной и обработанной земли будет давать урожая столько же, сколько раньше давали несколько гектаров. Важно выстраивать в агропромышленном комплексе эффективные бизнес-проекты, делать ставку на кооперацию малых форм хозяйствования, поддержку доходогенерирующих проектов, поддержку сельхозкластеров, фермерских хозяйств.

Нужно расширять экспорт, в первую очередь несырьевой. У республики есть возможность поставлять за рубеж брендовую продукцию из меда, мясные деликатесы, продукты халяль. Надо позиционировать Башкортостан как территорию натуральной и экологически чистой продукции.

Одной из главных задач является необходимость создавать на селе новые рабочие места, повышать доходы селян, улучшать условия их жизни и труда. Основными проблемами являются: отток молодежи на заработки в другие регионы, водоснабжением оснащены всего $60 \%$ сельских территорий, всего лишь 58\% сел газифицированы. Тысячи семей нуждаются в улучшении жилищных условий. Все эти проблемы республике необходимо решать.

Экспорт продукции агропромышленного комплекса Башкортостана вырос почти в 3 раза.
В числе основных стран-импортеров башкирской сельскохозяйственной продукции - Иран, Казахстан, Латвия, Саудовская Аравия, Узбекистан и Турция.

По данным Министерства сельского хозяйства Республики Башкортостан, приоритетными направлениями экспорта являются продукция пищевой перерабатывающей промышленности, а также масложировая и зерновая продукция.

Преимущественно экспортируются ячмень, пшеница, сахар. Помимо этого экспортируются подсолнечное масло, семена льна, посевной материал, кормовые растения, молочная продукция, яйца, мед.

В 2018 году Республика Башкортостан впервые поставила в Европу рапсовое масло, где из него вырабатывают биодизельное топливо. Первые партии отправил Чишминский маслоэкстракционный завод.

Потенциал республики позволяет расширить ассортимент экспортируемой продукции за счет стимуляторов роста растений, биопрепаратов, племенного яйца, племенного скота, чая и сиропов из лекарственных трав.

Сегодня в аграрном секторе экономики реализуется около 40 приоритетных инвестиционных проектов общей стоимостью 80 млрд. руб., создано около трех тысяч рабочих мест.

За последние три года реализовано пять инвестиционных проектов. В Благоварском районе построен комбикормовой цех. В совхозе «Алексеевский» появилась теплица площадью 2,5 га. Завершено строительство молочного завода в Уфе, элеватора и маслоэкстракционного завода в Кумертау.

В 2018 году завершена реализация пяти инвестиционных проектов. Это создание селекционно-генетического центра в области свиноводства, цеха переработки мяса, комбикормового завода на базе Давлекановского комбината хлебопродуктов, хладобойни «Строганов» в Мелеузовском районе, организация

Таблица 2. Приоритетные направления развития отраслей агропромышленного комплекса до 2020 года

\begin{tabular}{|c|c|c|}
\hline Растениеводство & Животноводство & $\begin{array}{c}\text { Пищевая и перерабатывающая } \\
\text { промышленность }\end{array}$ \\
\hline $\begin{array}{l}\text { 1. Производство зерна } \\
\text { 2. Производство и переработка } \\
\text { сахарной свеклы } \\
\text { 3. Производство овощей открытого } \\
\text { и закрытого грунта } \\
\text { 4. Производство масличных куль- } \\
\text { тур }\end{array}$ & $\begin{array}{l}\text { 1. Развитие молочного скотовод- } \\
\text { ства, увеличение объемов произ- } \\
\text { водства товарного молока } \\
\text { 2. Наращивание объемов произ- } \\
\text { водства мяса КРС, птицы, свини- } \\
\text { ны, столового яйца }\end{array}$ & $\begin{array}{l}\text { 1. Увеличение доли республи- } \\
\text { канской продукции в розничной } \\
\text { торговле } \\
\text { 2. Развитие экспорта продукции } \\
\text { агропромышленного комплекса }\end{array}$ \\
\hline
\end{tabular}


производства и реализации сублимированных экологически безопасных продуктов - башкирского кумыса.

Чтобы обеспечить более высокую динамику роста сельского хозяйства, нужны новые крупные проекты.

В республике работают шесть с половиной тысяч фермерских хозяйств. Они производят 11 процентов всей сельскохозяйственной продукции региона. В рейтинге Российской Федерации по объему валовой продукции фермерские хозяйства занимают 11-е место, в ПФО - четвертое.

Фермерами республики производится около 30 процентов зерна, около 25 процентов подсолнечника, около 20 процентов сахарной свеклы, 14 процентов овощей закрытого грунта, 5 процентов мяса и около 10 процентов молока.

В 2018 году начата программа по реализации доходогенерирующих проектов на основе инициативы граждан при создании сельскохозяйственных потребительских кооперативов (постановление Правительства РБ от 08.06.2018 года № 254).

По доходогенерирующим проектам, основанным на гражданских инициативах, по созданию сельскохозяйственных потребительских кооперативов проведена циклическая работа:

1 этап - изучение ресурсного потенциала территорий;

2 этап - формирование первичных групповых собраний

3 этап - целевое сопровождение по организации работы.

Финансирование по доходогенерирующим проектам, основанным на инициативах населения осуществляется в следующем порядке: собственные средства - 9\%, грант до 3 млн. руб.

Было проведено 300 первичных собраний, охвачено 7,5 тысяч человек, создано 450 инициативных групп. В результате проделанной работы были получены следующие результаты:
1. Количество вновь создаваемых СПоК, осуществляющих свою деятельность в РБ - 116 ед.

2. Количество ЛПХ и К(Ф)Х, вновь вовлекаемых в СПоК - 1300 ед.

3. Ежегодный рост доходов сельского населения, участвующих в реализации ДГП и объединившихся в СПоК $-10 \%$;

4. Количество новых рабочих мест в вновь создаваемых СПоК, осуществляющих свою деятельность в Республике Башкортостан - 300 ед.

Механизмы стимулирования развития сельскохозяйственной кооперации следующие:

1. Грант на развитие материально-технической базы сельскохозяйственного потребительского кооператива $(40 \%$ - собственные средства СПоК, 60\% - средства гранта (до 10 млн. руб.)).

2. Грант на развитие семейной животноводческой фермы (40\% - собственные средства фермера, $60 \%$ - средства гранта (до 10 млн. руб.)).

3. Грант на поддержку начинающего фермера (10\% - собственные средства фермера, 90\% - средства гранта (до 3 млн. руб.)).

На грантовую поддержку этих проектов было выделено 300 млн. руб. Деньги получили более тысячи малых сельхозпроизводителей (ЛПХ, КФХ, ООО, СТП).

За последние 5 лет в рамках программы обновления машинно-тракторного парка сельхозтоваропроизводителями республики приобретено более 14 тысяч единиц техники. В результате снижены износ, средний возраст техники, нагрузка при выполнении механизированных работ. При этом с учетом ежегодного списания дополнительно требуются не менее 1200 комбайнов и 3000 тракторов различного класса.

Показатели технической обеспеченности основными видами техники представлены в таблице 3.

\section{Таблица 3. Показатели технической обеспеченности основными видами техники}

\begin{tabular}{|l|c|c|}
\hline \multicolumn{1}{|c|}{ Наименование показателей } & \multicolumn{2}{|c|}{ По Республике Башкортостан } \\
\cline { 2 - 3 } & 2018 год & Целевые значения \\
\hline 1. Нагрузка на 1 трактор, га пашни & 225 & 180 \\
\hline 2. Количество тракторов на 1000 га пашни, шт. & 4,5 & 6,0 \\
\hline 3. Нагрузка на 1 зерноуборочный комбайн, га & 460 & $2,9 / 3,0 / 3,5$ \\
\hline $\begin{array}{l}\text { 4. Количество комбайнов на 1000 га посевной площади, } \\
\text { шт. (зерно/кормо/свеклоуборочных) }\end{array}$ & $2,2 / 2,4 / 3,0$ & 230 \\
\hline 5. Энергообеспеченность, л.с. на 100 га посевной площади & 176 & 2 \\
\hline
\end{tabular}


Ставка делается на собственное производство техники. Предприятиями республики освоено около 130 наименований различных видов новой сельскохозяйственной техники и оборудования. Например, производство самоходной косилки КС-100 «Чулпан» на базе «БашАгроМаш», зерноуборочного комбайна «Муромец-1500»ПО «Муромец» Стерлитамакского района, сборка колесного трактора Т-150K на базе Чишминского филиала «Башсельхозтехники».

В 2018 году на предприятии «Башсельхозтехника» впервые в России собрали трактор «Беларус-1221.3» - один из самых популярных тракторов, предназначенных для выполнения различных сельскохозяйственных работ.

Главное преимущество собираемой в Башкортостане сельскохозяйственной техники заключается в том, что аграрии региона могут приобрести ее с помощью частичного субсидирования из республиканского бюджета.

В 2018 году на обновление сельскохозяйственной техники из республиканского бюджета направлено 1,150 млрд. руб. В 2019 году выделено еще около 800 млн. руб. в виде субсидий. Все они идут на возмещение затрат сельхозтоваропроизводителей по приобретению сельхозтехники. Сборка тракторов «Беларус-1221.3», осуществляемая в Республике Башкортостан, попадает под республиканскую программу субсидирования.

В Министерстве сельского хозяйства Республики Башкортостан считают, что нужно уходить от производства сырья и осваивать переработку, которая дает высокую добавленную стоимость (муку, макароны, сыры и т.д.). Для этого в рамках реализации доходогенерирующих проектов в первую очередь будут поддерживаться проекты, предусматривающие переработку сельскохозяйственной продукции. Также в 2018 году расширили перечень субсидируемой техники, включив в него оборудование по переработке.

Сегодня во всем мире актуальна тема производства органической продукции, более того, рынок этой продукции сегодня самый динамично развивающийся: ежегодно он увеличивается на 15-16 процентов. Башкортостан вошел в число регионов, в которых будут внедрять пилотный проект по органическому сельскому хозяйству. Как считают эксперты, освоить такую форму производства республика сможет в течение двух лет. Преимуществом региона в этом направлении является наличие нетронутых пахотных земель - более 200 тыс. га земли. И это, прежде всего, районы северо-востока и Зауралья.

Развитие аграрного сектора экономики невозможно без государственной поддержки. На субсидирование аграрного сектора экономики республики ежегодно направляется около шести миллиардов бюджетных рублей. Поддерживают производство молока, племенное животноводство, область растениеводства и почвенного плодородия. Выделяются субсидии на приобретение техники и возмещение процентных ставок по кредитам. Для повышения конкурентоспособности российской сельскохозяйственной продукции Правительством РФ было принято решение о выделении дополнительных средств на дизтопливо.

Таким образом, сельское хозяйство в Республике Башкортостан успешно развивается. Башкортостан лидирует в стране по производству молока, мяса, меда, кумыса, поголовью лошадей, крупного рогатого скота. По общим объемам сельскохозяйственной продукции республика уверенно входит в первую десятку регионов. Предприятия республики производят почти весь ассортимент основных продуктов питания. Башкортостан полностью обеспечивает себя молочной продукцией, сахаром, говядиной, яйцами.

\section{Библиографический список}

1. Министерство сельского хозяйства РФ [Электронный ресурс]. Режим доступа: http://www.mcx.ru/ (дата обращения 02.11.2017).

2. Территориальный орган Федеральной службы государственной статистики по Республике Башкортостан [Электронный ресурс]. Режим доступа: http://bashstat.gks.ru/(дата обращения 07.11.2017). 